PRINT ISSN 1119-8362

Electronic ISSN 1119-8362
Full-text Available Online at https://www.ajol.info/index.php/jasem http://ww.bioline.org.br/ja
J. Appl. Sci. Environ. Manage. Vol. 25 (1) 79-85 January 2021

\title{
Factors Influencing Soil Erosion Management Practices in Ejersa Lafo District, West Showa Zone, Oromia, Regional State, Ethiopia
}

${ }^{* 1}$ AMENU LETA; ${ }^{2 T E R E F E ~ M E G E R S A ~}$

\author{
${ }^{*}$ Department of Agricultural Economics, College of Agriculture and Veterinary Science, Po.Box19, Ambo University, Ethiopia \\ ${ }^{2}$ Department of Rural Development, College of Agriculture and Forestry, Mettu University, Ethiopia \\ *Corresponding Author Email: amenuleta@gmail.com
}

\begin{abstract}
Soil erosion by water is the major Agricultural problem, which results in reduction of agricultural productivity. This study focused on farmer perception of soil erosion and factors influence soil erosion management practices. A cross sectional data was used to assess information about soil erosion perception and factors influence soil erosion management practices. The Ejersa Lafo district was purposively selected from the districts of West Shoa Zones. A total of 142 sample respondents were randomly selected. Interview questionnaire, focus group discussion and survey of field observation were used as data collection tools. Data were analyzed using descriptive statistics and econometric model. Result from descriptive statistics show that majority of the respondents perceived soil erosion problem and its consequence on farmland. Both biological and physical soil erosion management practices in the area. Binary logit model estimation result shows that education level, landholding size, slopes of the land and land ownership type were most significant to soil erosion management practices in the area. Therefore, taking these factors into account in setting appropriate soil erosion management measures may help policy makers and farmers to couple with erosion problem. The study recommended a need for the government to enforce effective policies to control and prevent soil erosion problem.
\end{abstract}

\section{DOI:https://dx.doi.org/10.4314/jasem.v25i1.11}

Copyright:Copyright $(\subset)$ 2021Amenu and Terefe. This is an open access article distributed under the Creative Commons Attribution License (CCL), which permits unrestricted use, distribution, and reproduction in any medium, provided the original work is properly cited.

Dates: Received: 02 October 2020; Revised: 26 November 2020; Accepted: 12 December 2020

Keywords: Binary logit model: Management practices: Soil Erosion

Soil erosion is a main environmental and agricultural problem that affects worldwidly more than 10 million hectares per year (World Economic Forum, 2010).Likewise Mohamed (2015) recognized that soil erosion is serious environmental problems in the world and is responsible for $80 \%$ of the current degradation of agricultural.Soil degradation induced by water erosion in sub Saharan Africa (SSA) is mainly concerned because of its consequences on subsistence agriculture, from which about $85 \%$ of the population derives their livelihoods (Erkossa et al., 2015; Tully et al.,2015).It is a major threat to development in most economies of the world (Erkossaet al., 2015; Taguas et al., 2015; Keesstra et al., 2016). About 15\% of land worldwide is degraded, of which $16 \%$ is in Africa (Jarecki, M. K, 2003; Kumar, K. V. et al., 2008). Similarly TesfaandMekuriaw (2014) indicated that natural resource degradation is the environmental problems which resulting for decline of agricultural productivity.According to Assogba et al.,(2017) revealed that in the many agroecological areas, erosion has leach the top soil.According to Kidane and Alemu (2015) concluded that soil erosion problem is more severe in the highlands of Ethiopia.Among the Sub Saharan Africa countries, Ethiopia has a suffered by

*Corresponding Author Email: amenuleta@gmail.com high level of soil erosion (Mekonnenet al., 2016; Simachew A.et al., 2016). Soil erosion and nutrient depletion are two particularly common sources of declining agricultural productivity in Ethiopia. Empirical studies have linked low and declining crop yield to the existence of severe soil erosion (Amdihun, et. al., 2014;BrkalemShewatatek, 2015). However, factor affecting soil erosion management practices were not studied in the study area. Therefore, the study aimed to identify farmers perception of soil erosion and factors influencing implementation of soil erosion management practice in EjersaLafo District.

\section{MATERIALS AND METHODS}

Discription of the Study Area:The study was conducted in Western Shoa Zone in EjersaLafodistrictwhich is located in Eastern part of west Shoa Zone of Oromia National regional State Ethiopia. It covers an area of 35,176.09 ha and has a population of 45,895 . Administratively the district is divided into 17 rural and 3 urban kebeles totally 20 kebeles. Crop farming and livestock rearing are the major sources of livelihood for the population of the district, like many other rural areas of the region. The farming system is a typical cereal-based crop-livestock mixed farming system(Figure 1a and $b$ ). 


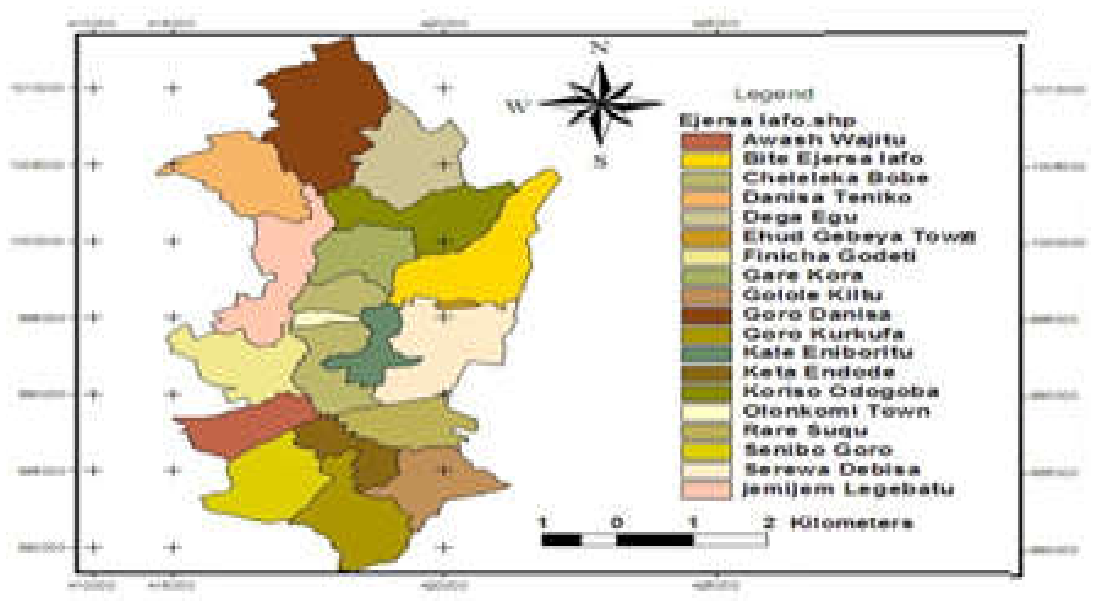

Fig: 1a. Map of Ejersa lafo district

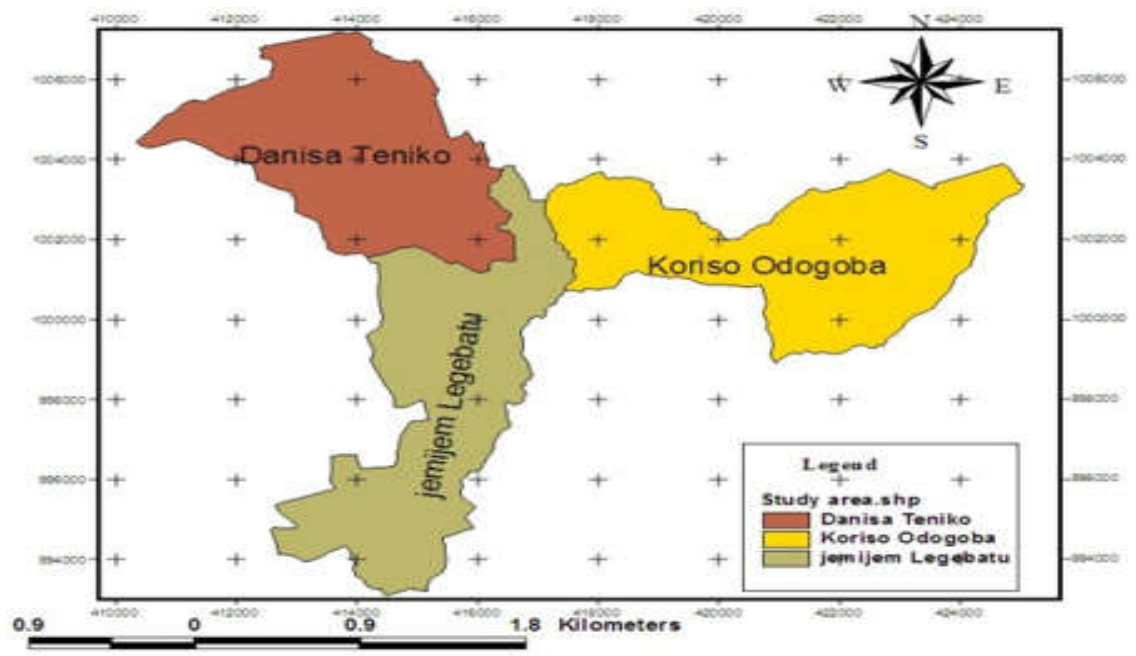

Fig: 1b. selected kebeles of the study area

Sample size and Sampling technique:TheEjersaLafo district was purposively selected on the basis of the soil erosion management practice with utilizing of different project like sustainable land management project (SLMP) and Agricultural growth production (AGP). Further, there is no research undertaken in the study area about farmer perception of soil erosion and factor hinders soil erosion management practice in the area. Once the district is select as a study area, sample of peasant association were selected by using simple random sampling technique. In this case, among the existing 20 kebeles, only three kebeles, namely (DanisaTanco, Jemjem legebatu and Korisoodogoba) were randomly selected. The sample frame for selected kebeles would be prepared and the desired number of sample size was determined. The data used in this study came from detailed household and plot surveys of 142 farm households. To determine the required sample size Yamane (1967) was employed at 95\% confidence level, with a 0.05 degree of variability and $8 \%$ level of precision (margin error) can be determined as follows.

$$
\begin{gathered}
\mathrm{n}=\frac{\mathrm{N}}{1+\mathrm{N}(\mathbf{e}) 2} \\
\mathrm{n}=\frac{1567}{1+1567(0.08) 2}=142
\end{gathered}
$$

Where: $\mathrm{n}=$ sample size, $\mathrm{N}=$ Total number of household $\mathrm{e}=$ designate maximum variability or margin of error $8 \%$ ( 0.08 adapting be reviewing various literature), $1=$ designates the probability of the event occurring. Therefore, total sample size is 142 out of this (51) from Danisa Tanco, (49) from Jem jem legebatu and (41) from Korisoodogoba were selected based on proportion to number of household. 
Table 1: Sampling frame and sample size

\begin{tabular}{|c|c|c|c|c|c|c|}
\hline \multirow{2}{*}{$\begin{array}{l}\text { Name of } \\
\text { Sampled kebeles }\end{array}$} & \multicolumn{2}{|c|}{ Total No. of $\mathrm{HHs}$} & \multirow[t]{2}{*}{ Total } & \multicolumn{2}{|c|}{ Sampled HH } & \multirow[t]{2}{*}{ Total } \\
\hline & MMale & Fe Female & & Male & Female & \\
\hline DanisaTanco & 400 & 170 & 570 & 36 & 15 & 51 \\
\hline Jemiem legebatu & 438 & 100 & 538 & 40 & 9 & 49 \\
\hline Koriso odogoba & 381 & 68 & 449 & 35 & 7 & 42 \\
\hline Total & 1229 & 338 & 1567 & 111 & 31 & 142 \\
\hline
\end{tabular}

Data sources and Methods of data collection:Both primary and secondary data was used.Primary data on the demographic characteristics sample of households, extension services, income, education level, marital status, land size, land ownership, consequences of soil erosion, farmers' perception of soil erosion and soil control practice (biological and physical soil erosion management) while secondary data were obtained from the reports, books, journals, and documents from offices of Agricultural Development and Water Resources, Land and Environmental Protection at Zonal, District and kebeles level.Questioner survey, interview, focus group discussion and participant observation data collection tools were used. The questionnaire was designed and pre-tested in the field for its validity and content and to make overall improvement of the same and in line with the objectives of the study.

Method of Data Analysis:Descriptive statistics and econometric analysis were employed to analyze the data collected from sample respondents to meet the objectives of this study.

Descriptive statistics: Descriptive statistics frequencies, percentages and standard deviationand chi-square test were used to describe demographic characteristic and association between farmers' perception of soil erosion and explanatory variable.

Econometric model:Model specification is based on the nature of dependent variable. Since dependent variable was dummy variable, which takes a value Zero [0] if farmers not control/ manage/ soil erosion problem and [1] if farmers control/manage/ soil erosion problem. Under such condition binary logit and probit model was used to explain variation withsoil erosionmanagement and no soil erosion management practices by smallholder farmer.The reason why binary logit model was selected for this study over the logit model is because it has some advantage when sample size is small.In this study, the odds ratio is the ratio of the probability that the soil erosion management[Pi] to the probability that he/she will be on soil erosion management measure[1-Pi].

$$
\begin{aligned}
& p i=f(Z i)=f(\alpha+\beta i \chi i) \\
& (1-p i)=\frac{1}{1+e^{Z i}}\left(\frac{p i}{1-p i}\right)=\frac{1+e^{Z i}}{1+e^{-Z i}}=e^{Z i}
\end{aligned}
$$

$$
\left(\frac{p i}{1-p i}\right)=\frac{1+e^{Z i}}{1+e^{-Z i}}=e^{(\alpha+\Delta \beta i+\chi i)}
$$

Taking the natural logarithm from above equation

$$
Z i=\beta 0+\Sigma \beta 0 X i+U i
$$

A binary logistic regression model was fitted to estimate the effect of expected explanatory variables on the probability of a farmer being control soil erosion (or not).

\section{RESULTS AND DISCUSSION}

Farmers' perception of soil erosion:Survey results indicated that about38\% of farmers understood thatsoil erosion ashigh problem in farmlands while $29.6 \%$ of farmers demonstrated the intensity of soil erosion isslow in cropland. This entails inventiveness to manage soil erosion through sustainable land management technologies and involvements of local communities. This implied that perception to soil erosion positively correlated with soil erosion management practices/ technologies. Farmers with better perception of soil erosion will develop good initiations towards soil erosion management.

Table 2: Farmer perception of soil erosion problem

\begin{tabular}{lllll}
\hline No & Perceived soil erosion & Frequency & Percent & Chi square $\left(\chi^{2}\right)$ \\
\hline 1 & Low problem & 42 & 29.6 & \\
2 & Medium problem & 46 & 32.4 & 0.046 \\
3 & High problem & 54 & 38 & \\
& Total Respondents & 142 & 100 & \\
& Mean & 2.77 & & \\
& Std deviation & 1.081 & & \\
\hline
\end{tabular}

The findings indicated that most of the respondents either agreed or disagreed that the rate of soil erosion is sometimes a problem for all of our cultivated field with a mean of 2.7 , so, it is important to apply soil erosion management practices for minimizing the rate of soil erosion. Chi square test also shows statistically significant difference between the farmers perception of soil erosion status in the study area $\left(\chi^{2}=0.046 ; \mathrm{P}<\right.$ 0.05).

Demographic characteristics of the respondents: Respondents' distribution by gender: The total households in EjersaLafo district of three Kebeles were selected 142 of which about 111 were male headed and 31 by females. This implies that greater percentages of the farmers in the research area are male. Conditions that suggest gender discrimination with respect to agriculture, and farming activities are 
male dominated in the study area. However, the smaller percentage of female farmers sampled is reflective of the fact that women in general, and in the study area in particular depend on their husbands for a livelihood. The women rarely claim ownership of farms and usually regard males as the owners of the family farm land.

Respondents distribution by age: As survey study indicated the average age of sampled farmer were with age 31-40, 41-60 and above age of 60 were 33.1, 56.3, and $10.6 \%$, respectively. This suggests the farmers are still in their economically active stage of agefarmers of middle-aged generally, influence many farming activities, especially in terms of increased hectares of farmlands and soil erosion management practices. Moreover, the peasant administrations (PA) of middleaged are more enthusiastic and have more physical vigor and family responsibilities than the young and old farmers.

Respondents distribution by educational status: Majority of the respondents (40.1\%) were illiterates, the rest are reading and writing through basic education and religious schools(13.4\%), other (36.6\%) respondents were primary school. The greatest percentage of farmers sampled are illiterate. The low proportion of literates in the respondent's groups implies that the majority of them arenot aware or understand soil erosion management practices.

Respondents' distribution by marital status:The $58.5 \%$ of the sampled farmers are married, $18.3 \%$ unmarried while, only $17.6 \%$ and $5.6 \%$ were divorced/widowed and unmarried respectively.

Land holding size of respondent:All of the interviewed farmers owned land. The mean holding farm size is about $0.5 \mathrm{ha}$. The significances variation in the size of land holding among sampled households. Majority farmer $(42.3 \%)$ possessed above 2 ha of lands where $21.1 \%$ e about $1.5 \mathrm{ha}-2 \mathrm{ha}$, at $16.2 \%$ farmers e 1 ha$1.5 \mathrm{ha}$, at $14.1 \%$ about $0.5 \mathrm{ha}-1 \mathrm{ha}$ and $6.3 \%$ approximately 0.5 ha.

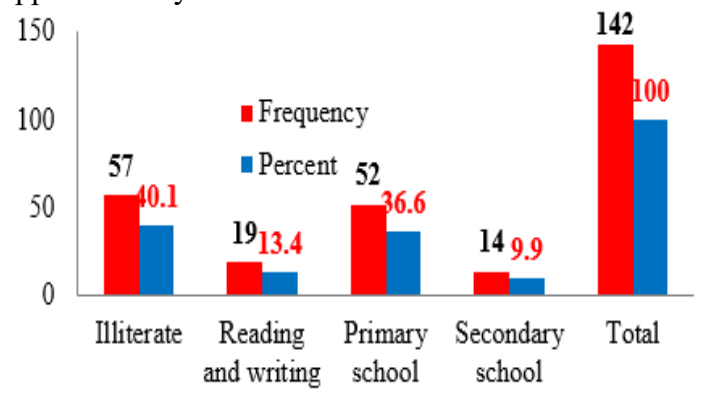

Fig: 2. Education level of respondent

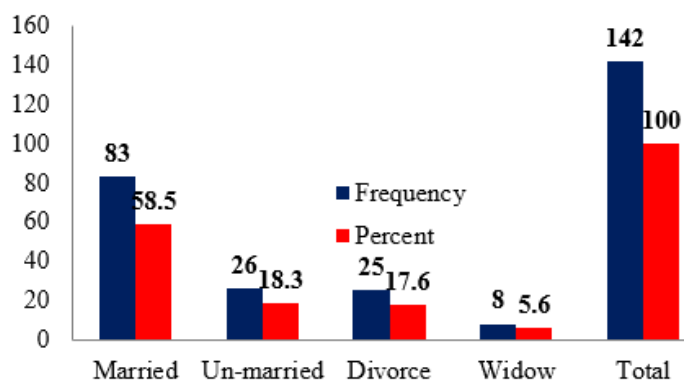

Fig: 3. Marrital status of respondents

Distance of cultivation land from Homestead: Distance from cultivation land to homestead influence the soil erosion management practices. The feasible explanation is that the nearer the cultivation fields to the homestead, the frequent the land management and soil and water conservation measures and the higher will be practice of conservation measures (Assefa 2009). It was indicated that farmers having land far from their residence usually do not visit to their cultivation field except during harvesting and planting season. In other side of these, there were farmers whose land is here and there, but the field that exists far fromhomestead has been given for share cropping and left for grazing mostly without soil erosion management practices. Only $23.2 \%$ of respondents 5 10 minutes' walk, $69 \%$ with 10-20 minutes' walk and $7.7 \%$ with $20-30$ minutes walks.

Land ownerships :Survey result show that soil bund were poorly maintenance specially those who rented land $(8.5 \%)$, share cropping $(8.5 \%)$ from landholder.Farmers does not give attention for maintenance of already constructed soil bunds due to need of immediate return and they believe that bunds can decrease their farm size and inherited from parent $(83.1 \%)$ give more attention.

Extension services/ training:The 82 respondents ( $57.7 \%$ ) were having access to the soil erosion management extension services while $42.2 \%$ were not having access to the soil erosion management extension services.

Slope of land:Survey result show that about 45.6, 35.6 and $18.8 \%$ of farmlandwere steep, flat and medium slope respectively in the study area.

Farmer perception to causes of soil erosion: Survey result show that about 23.9, 19.7, 16.9, 9.2 and $4.9 \%$ of sample respondents reported inappropriate land use, overgrazing, intensity of rainfall, deforestation and lack of ground water respectively as the major cause of soil erosion. Moreover, 23.9 and $19.7 \%$ of the 
farmers considered inappropriate land use and the overgrazing respectively as the major cause of soil erosion on their land. Moreover $31.6 \%$ of the respondents reported population growth as the major cause of soil erosion. Chi square test also shows statistically significant difference between the causes of soil erosion in the study area $\left(\chi^{2}=0.034 ; \mathrm{P}<\right.$ 0.05 )

Table 3: Causes of soil Erosion identified in the study area

\begin{tabular}{llll}
\hline Causes of soil erosion & \multicolumn{2}{c}{ Farmers responses } & \multirow{2}{*}{$\begin{array}{c}\text { Chi } \\
\text { square }(\chi 2)\end{array}$} \\
\cline { 2 - 3 } & No & Percent & \\
\cline { 1 - 2 } $\begin{array}{l}\text { Inappropriate land Use } \\
\text { practices }\end{array}$ & 34 & 23.9 & 0.034 \\
Overgrazing & 28 & 19.7 & \\
Deforestation & 13 & 9.2 & \\
Intensity of rainfall & 24 & 16.9 & \\
Lack of ground cover & 7 & 4.9 & \\
over winter time & & & \\
Population growth & 45 & 31.6 & \\
Total & 142 & 100 & \\
\hline
\end{tabular}

Farmers' perception to consequences of soil erosion: The most of the respondents were aware of $45.9 \%$ loss of agricultural productivity. The loss of productivity due to loss of topsoil by $33 \%$, siltation of waterways by $24.6 \%$, contamination of drinking water by $20.4 \%$, reproduction of gullies by $12.7 \%$, Biodiversity loss by $10.5 \%$, and impacts on strategic reservoirs by $7 \%$. The major consequences of soil erosion in the study area are loss of productivity, loss of topsoil and siltation of water ways respectively.Chi square test also shows no statistically significant difference between the farmers' perception on consequences of soil erosion in the study area $(\chi 2=$ 7.32; $\mathrm{P}>0.05)$. This implies that soil erosion had similar negative effect in the study area.

Table 4: Consequences of soil erosion in the study area

\begin{tabular}{|c|c|c|c|}
\hline \multirow{2}{*}{$\begin{array}{l}\text { Consequences of } \\
\text { soil erosion }\end{array}$} & \multicolumn{2}{|c|}{ Farmers responses } & \multirow{2}{*}{$\begin{array}{l}\text { Chi square } \\
(\chi 2)\end{array}$} \\
\hline & No & Percent & \\
\hline Loss of & 15 & 10.5 & \\
\hline Biodiversity & & & 7.32 \\
\hline $\begin{array}{l}\text { Impacts on } \\
\text { strategic } \\
\text { reservoirs }\end{array}$ & 10 & 7.04 & \\
\hline $\begin{array}{l}\text { Contamination of } \\
\text { drinking water }\end{array}$ & 29 & 20.4 & \\
\hline $\begin{array}{l}\text { Reproduction of } \\
\text { gullies }\end{array}$ & 18 & 12.7 & \\
\hline $\begin{array}{l}\text { Siltation of } \\
\text { waterways }\end{array}$ & 35 & 24.6 & \\
\hline Loss of topsoil & 47 & 33 & \\
\hline $\begin{array}{l}\text { Loss of } \\
\text { productivity }\end{array}$ & 51 & 45.9 & \\
\hline Total & 142 & 100 & \\
\hline
\end{tabular}

Biological soil erosion management practices:Some of the biological soil erosion practices that practiced by the kebeles were crop rotation, intercropping, grass strip residue recycling and contour farming. The use of crop rotation $(28.2 \%)$ and residue recycling (30.3\%) helps to increase soil organic matter, reduce erosion and bring biological diversity back to the soil. Intercropping system is a form of agronomic practices employed by farmers where different kinds of annual crops are planted in alternating rows for soil conservation to reduce soil erosion risk by providing better canopy cover than do sole crops (Moges and Holden, 2007, Kagabo et al., 2013).

\begin{tabular}{lll} 
Table 5:Biological soil erosion management in the study area \\
\hline Biological soil erosion management & \multicolumn{2}{c}{ Farmers responses } \\
\cline { 2 - 3 } & No & Percent \\
\hline Crop rotation & 40 & 28.2 \\
Inter cropping & 14 & 9.9 \\
Grass strip & 25 & 17.6 \\
Residue recycling & 43 & 30.3 \\
Contour farming & 20 & 14.1 \\
Total & 142 & 100 \\
\hline
\end{tabular}

Physical soil erosion management practices:Survey result identified that types of physical soil erosion control structure in the study area. these are soil bund(29.6\%), mulching (21.1\%), Cut-off drains(16.2\%), waterway (23.2\%) and Strip cropping $(9.9 \%)$ of the farmers have used these physical soil erosion management practice respectively. Moreover, soil bund and cut-off drain a major physical soil erosion management structure in the study area.

Table 6:Physical soil erosion managementin the study area

\begin{tabular}{lll}
\hline Physical soil erosion management & \multicolumn{2}{c}{ Farmers responses } \\
\cline { 2 - 3 } & No & Percent \\
\hline Soil bund & 42 & 29.6 \\
Mulching & 30 & 21.1 \\
Cut-off drains & 23 & 16.2 \\
Water ways & 33 & 23.2 \\
Strip cropping & 141 & 9.9 \\
Total & 142 & 100 \\
\hline
\end{tabular}

Econometric analysis of factors affecting soil erosion management:Before running the logistic regression analysis, the existence of multicollinearity among the explanatoryvariables was checked using variance inflation factor (VIF). The VIF values for all the explanatory variables were very small (much less than 10) indicating that absence of multicollinearity between the explanatory variables. and if VIF is greater than 10, then multicollinearity exists (Oddendo et al., 2010). Therefore, multicollinearity was not found to be a problem to this analysis. The likelihood ratio, goodness of fit test shows a good fit for the model. The $\chi 2$ statistics testing that the coefficients of the model excluding the constant term, are highly significant (at $\mathrm{P} \leq 0.001$ ) supporting the specification. The results are reported using odd ratio. The result of binary logit model show that from the total of nine independent variable assume to be factors affect soil erosion managements, four explanatory variable were significantly affect soil erosion management practices. 
These are education level, landholding size, slope of the land and land ownership types are statistical significant to soil erosion control in the study area. The interpretation of the four significant explanatory variables is discussed below:

Land holding size:Negatively influenced soil erosion management practicetindicate that decrease in land holding size, increases farmers' soil erosion control. The small farms in the study area frequently cultivated with soil erosion control. Theodd ratio for this variable shows that keeping other variables remain constant, the marginal effect suggests one unit decrease in land holding size would causes an increase soil erosion control by 1.88 percent. This is in line with the finding reported by Odendoet al. (2010) in rural Ethiopia, indicating indirect relationship between farmers` level of perception on soil erosion and their respective land holding size.

Educational level of household head:Education level of the household head was found to be positively significant influence on the soil erosion management practices. This implies that educated household head better understanding the problem of soil erosion and easily understood the new technology to land management. The odd ratio value for education shows that keeping all factors constant an increase in education by one year, the probability of soil erosion management practices household head is increased by 0.027 . The study in line with the finding of MbagaSemgalawe and Folmer( 2000) and Lapar and Ehui ( 2004) also observed that education has a positive impact in the adoption of improved soil conservation technology.

Slope of the land:Positively influence soil erosion management practices at $1 \%$ significant level. The significant positive terms in erosion management practices indicate that farmers invest conservation practices where their farm plots are located on steep slopes. The odd ratio value for slope of farm plot shows that keeping all factors constant, an increase in slope from flat to steep slope, the probability of investing soil erosion control structure is increased by 0.013 .

Land ownership:Land ownership positively correlated with soil erosion management. Land belongs to own the farmer more managed than rented, crop shared one. The lack of title to land is one important factor affecting soil erosion management practices because lack of land ownership means that people are unwilling to invest soil erosion management technology on land which they do not formally own. In references to rented and share crop land, the odd ratio in favour the probability of investing soil erosion control on owned land is increased by 3.1446 .

\begin{tabular}{|c|c|c|c|c|}
\hline Variable & Coef. & Std. Err. & $P>|z|$ & Odd ratio \\
\hline Sex & -.6216763 & .5835799 & 0.287 & -.0155823 \\
\hline Age of respondent & -.016866 & .0230585 & 0.465 & -.0004021 \\
\hline Education level & $1.133602 * *$ & .3466843 & 0.001 & .0270283 \\
\hline Marital status & -.1038469 & .6341202 & 0.870 & -.0022945 \\
\hline Land size & $-.9006707 * *$ & .3211383 & 0.005 & .0188438 \\
\hline Slope & $* *$ & .12272 & 0.000 & .0131701 \\
\hline Income & .5762166 & 1.114486 & 0.605 & .0120556 \\
\hline ESE & -.0146374 & .0134353 & 0.276 & -.0030638 \\
\hline Land ownership & $.000015 * *$ & 7.0666 & 0.000 & 3.1446 \\
\hline Log likelihood $=-1$ & $6.451, \mathrm{~N}=142$, & $\operatorname{LR} \operatorname{chi} 2(9)=$ & 107.55 & $\mathrm{P} \leq 0.001$ \\
\hline
\end{tabular}

Conclusion:This study attempted to assess farmers' perception of soil erosion problem and factors that influence soil erosion management practices in the EjersaLafo Districts.Even if biological and physical soil management practices, the problem of soil erosion was increase time to time in the study area. To addresses the proble identified factors influencing soil eriosion management is crucial.The results obtained from binary logit model indicate thateducation level, landholding size, slope of the landand land ownership types are significantly affect the probability that farmer managesoil erosion problem.it is suggested that government and non government supporters are needed to encourage soil erosion management practices on the agricultural lands through take into the account the significant variable identified and discourage uncontrolled cropping of agricultural use on affected agricultural land areas. Therefore, policies aiming at promoting sustainable soil erosion management practices need to emphasize the crucial role of continuous investment by providing information on better management practices to enable farmers to increase agricultural production.

Acknowledgements: The authors would like to acknowledge the data collectors,DAs,farmers, Kebele PAs, and Agricultural and Natural resources offices for their unreserved support.

\section{REFERENCE}

Amdihun A, Gebremariam E, Rebelo L and Zeleke G (2014). Suitability and scenario modeling to support soil and water conservation interventions 
in the Blue Nile Basin. Ethiopia. Environmental Systems Research 3: 1-13.

Assogba SCG, Akpinfa E, Gouwakinnou G and Larissa S. (2017). La Gestion Durable des Terres: Analyse d'expériences de projets de développement agricole au Bénin (Rapport de Synthèse, p. 32).

Brevik EC, Cerdà A, Mataix-Solera J, Pereg L, Quinton JN, Six J and Van Oost K. (2015). The interdisciplinary nature of soil. Soil 1(1): 117-129.

Erkossa T, Wudneh A, Desalegn B and Taye G (2015). Linking soil erosion to on-site financial cost: Lessons from watersheds in the Blue Nile basin. Solid Earth 6(2): 765-774.

Gao X, Xie Y, Liu G, Liu B and Duan X. (2015). Effects of soil erosion on soybean yield as estimated by simulating gradually.

García Ruiz JM, Beguería S, Nadal-Romer E, González-Hidalgo JC, Lana-Renault $\mathrm{N}$ and Sanjuán Y (2015). A meta-analysis of soil erosion rates across the world. Geomorphology 239: 160173.

Hurni H, Solomon A, Bantider A, Debele B, Ludi E, Portne RB and Zeleke G (2010). Land degradation and sustainable land management in the Highlands of Ethiopia. In H. Hurni and U. Wiesmann (Eds.), Global change and Sustainable Development. A Synthesis of Regional Experiences from Research Partnerships. University of Bern, Geographica Bernensia, Perspectives of the Swiss National Centre of Competence in Research (NCCR) North-South Vol. 5. Bern, CDE. 187-207.

Keesstra SD, Bouma J, Wallinga J, Tittonell P, Smith $\mathrm{P}$, Cerdà $\mathrm{A}$ and Bardgett $\mathrm{RD}$ (2016). The significance of soils and soil science towards realization of the United Nations Sustainable Development Goals. Soil 2: 111-128.

Kidane D and Alemu B. (2015). The effect of upstream land use practices on soil erosion and sedimentation in the upper Blue Nile, Ethiopia highlands.

Kumar KV and Bai RK (2008). Performance study on solar still with enhanced condensation. Desalination 230(1-3): 51-61.

Mekonnen M and Hoekstra AY.( 2016). Four billion people facing severe water scarcity. Science Advances 2(2): e1500323.

Muluneh A, Stroosnijder L, Keesstra S and Biazin B (2017). Adapting to climate change for food security in the Rift Valley dry lands of Ethiopia: supplemental irrigation, plant density and sowing date. The Journal of Agricultural Science 155(5): 703-724.

Panagos P, Borrelli P, Meusburger K, Yu B, Klik A, Lim KJ and Sadeghi SH (2017). Global rainfall erosivity assessment based on high-temporal resolution rainfall records. Scientific Reports 7(1): 4175 .

Panagos P, Borrelli P, Poesen J, Ballabio C, Lugato E, Meusburger K and Alewell C. (2015). The new assessment of soil loss by water erosion in Europe. Environmental Science and Policy 54: 438-447.

Shewatatek B (2015). Econometrics model on determinants of adoption and continued use of improved soil and water conservation practices: The case of Boloso-sore Woreda of Wolaita zone, Ethiopia. Scholarly Journal of Scientific Research and Essay 4(2): 35-42.

Simache A, Lanzén A, Gessesse A and Øvreås L. (2016). Prokaryotic community diversity along an increasing salt gradient in a soda ash concentration pond. Microbial Ecology 71(2): 326-338.

Simeneh D and Getachew F. (2015). Perception of farmers towards physical soil and water conservation structures in Wyebla Watershed, Northwest Ethiopia. Academic Journal of Plant Sciences 7(3): 34-40.

Taguas EV, Guzmán E, Guzmán G, Vanwalleghem T and Gómez JA. (2015). Characteristics and importance of rill and gully erosion: a case study in a small catchment of a marginal olive grove. Cuadernos de investigacióngeográfica 41(1): 107 126.

Tesfa A and Mekuriaw S. (2014). The effect of land degradation on farm size dynamics and croplivestock farming system in Ethiopia: A Review. Open Journal of Soil Science 4(01): 1-10.

ully K, Sullivan C, Weil R and Sanchez P. (2015). The state of soil degradation in sub-Saharan Africa: Baselines, trajectories, and solutions. Sustainability 7: 6523-6552.

Wolka K. (2014). Effect of soil and water conservation measures and challenges for its adoption: Ethiopia in Focus. Journal of Environmental science and Technology 7(4): 185-199.

Yamane T. (1967). Solutions to Problems to accompany Statistics, An introductory analysis. 2nd Edition ,Harper and Row, New York. 